\title{
Pembe. The Empire blanched in fear, anger and shame.
}

\author{
Marco Fortunato Arrifes \\ Ministry of National Defence \\ Lisbon, Portugal \\ marrifes@gmail.com
}

\section{Introduction}

On 25 September 1904, a military column that had been deployed to occupy the Kwanyama region in southern Angola was attacked and severely defeated by the Kwamatos. Over two hundred Portuguese soldiers are thought to have died in the fight, of which 109 were Europeans and 145 were Africans.

The column left Lubango on 22 August and reached the Humbe, the furthest reach of Portuguese influence in the region, on 11 September. The going was slow because of the rugged terrain and the sluggish Boer cars, and the lack of water made the march toilsome, but it was nonetheless conducted in an organized manner, and there were no major incidents.

On 19 September, the column, which had meanwhile been reinforced with indigenous companies and auxiliaries, was put in motion, and after $2 \mathrm{Kms}$ the troops began crossing the Cunene River. The crossing took a day and a half, with the troops already under Kwamato fire. The Battle of the Ford of Pembe had begun ${ }^{1}$.

The forces commanded by Captain João Maria Aguiar, Governor of Huila Province, bivouacked in square once they reached the left bank of the river. The bulk of the troops remained stationed there for six days, during which they were buffeted with constant lowintensity attacks.

On the 23rd, an offensive reconnaissance action commanded by then Captain Gomes da Costa came into direct confrontation with the Kwamatos, who did not put up significant resistance. The troops took advantage of the opportunity to set fire to a few libatas [dwellings] and to carry out a more thorough reconnaissance of the surrounding territory. Two days later, a new detachment entered the woods, this time commanded by Captain Pinto de Almeida and, approximately $8 \mathrm{Kms}$ from the main column, in the Umpungo chana $^{2}$, it was surrounded by Kwamato forces and completely destroyed. A few retreating soldiers were even hit by friendly fire from the artillery stationed along the river.

\footnotetext{
${ }^{1}$ For a detailed analysis of the development of this conflict see Borja (1904), Almeida (1904), Moraes (2007), Salgado (2011).

2 Plain.
} 
That same day, the survivors retreated toward Humbe, crossing the Cunene in only three hours, leaving behind provisions, wine barrels, wire, all the zinc sheets they had used to protect the trenches, which had been built to protect the square, and many heavy supplies.

A thunderstorm had meanwhile broken below the plateau, hindering telegraphic communications. Still, the first news of this upsetting event reached Moçâmedes as early as the 28th. Uncertainty and incredulity abounded during those first few days, but feelings of consternation and revolt soon began to spread. In Portugal, it was not until October that the initial reports were disclosed to great commotion. Displays of grief and religious ceremonies in honour of the dead multiplied across the country, while heated discussions erupted in the two houses of parliament, led by representatives of the Progressive Party, the opposition party at the time.

At the same time, there were calls for punitive expeditions, and several disciplinary inquiries were launched which culminated with the appearance of the commander of the expedition before the War Council. The thinking produced by military circles, which sought to find an explanation for the events, often opened up new advanced platforms of analysis for the organics of the military mechanisms overseas.

\section{Objectives}

Despite the deep sorrow felt in Portuguese society at the time having been overshadowed by more pressing issues on the political agenda, the campaign was actually a matter of some importance, which, in our opinion, makes it even harder to understand why it was barely mentioned in the years to come.

That importance was evidenced by the fact that, for the first time, Angola was the stage for the preparation and subsequent execution of the most modern operational and tactical mechanisms, such as forming square during battle, marching in double column, systematically organising reconnaissance operations, attempting to rationalise logistics or regulating stationing procedures.

These principles, which stemmed from the influence of the victories in the Mozambican campaigns of 1895, had already been used in the Bailundo and Humbe campaigns, but in Angola they were implemented in a fully integrated manner, based on two other critical lessons learnt in Mozambique. First, that it was necessary to secure superiority of arms to neutralize the overwhelming inferiority in terms of human assets, an aspect common to all European armies in Africa and, second, that there was a pressing need for troops from the mainland.

This campaign can thus be said to mark a break in southern Angola. There was a transition from a concept of conflict that often amounted to little more than a police action, or even a quarrel between brigands, or a belated display of a sort of romantic chivalry, to actual 
warfare actions which could still be described as relatively low-intensity, but undeniably fit into the definition of war as a 'state of conflict between political groups, in which armed force is employed and violence is used in an organized manner to accomplish the aims defined by policy'3 (...).

For different reasons, the results on the ground in September 1904 were not as expected, but the truth remains that all subsequent campaigns until the late 1920s, when the sovereignty claim process in southern Angola was concluded, were essentially built around these basic principles, including the actions of Alves Roçadas and Pereira d'Eça in 1915.

Therefore, this work seeks to achieve three basic objectives. First, to understand the reasons for the silencing of this event by historiography. Second, to assess the political and social impact of the defeat, both in Angola and in the mainland, and finally, to ascertain, in general terms, the thinking produced at the time which attempted to uncover the causes of the defeat.

\section{Pembe in Historiography}

Regarding our first objective, which is to understand why this defeat fell into the oblivion of history, we will begin by pointing out that this historical silence is also noticeable in the fields of art and culture, from music to painting, film or literature.

Indeed, and despite the different aspects of the military niche having inspired areas as diverse as film, painting, music and even comic books, in reality none of those areas deemed the facts related to Pembe worthy of attention.

Over the last century, for example, our Literature produced some of the most memorable moments in national culture, where military themes were highly developed and the various African wars in Portuguese history were often either the protagonists or the background for multiple storylines. However, Pembe is almost a banned subject, only mentioned in passing in four or five novels, the most prominent of which were written by Angolan authors Pepetela and José Eduardo Agualusa, the latter from whom we borrowed the title of our work ${ }^{4}$.

\footnotetext{
${ }^{3}$ Barrento, 2010, p. 85.

${ }^{4}$ In Os Colonos, António Trabulo presents a romanticized view of the colonization of southern Angola; the reference to Pembe is circumstantial and takes up only seven lines. Both José Eduardo Agualusa, in his novel A Conjura and in the short story collection A Estação das Chuvas, and Pepetela, in Yaka were able to use the sharpness of their writing to produce a few pages of dazzling creativity based on the event.
} 
We do not intend to cast any kind of aspersions by mentioning this ontological absence of Pembe from the domains of artistic creation; it is simply a fact, and one that we do not intend to discuss here.

In any case, this was one of the largest Portuguese defeats in Africa, and considering the impression those dark lands left on the national imagination, it seems that the issue of the defeat, which could in itself be an explanation for such an oblivion, especially in times of mythological construction, cannot be the only way to explain the phenomenon we call the silencing of Pembe.

In order to do this, we believe we must call upon other dimensions, including the lack of dissemination of the topic in the domains of official or academic memory, which alone has rendered it inadequate as a basis for creativity. That is, one cannot create on what one does not know.

Here we enter the domain of historiography, the field of knowledge responsible for consolidating and making available the knowledge of the past, regardless of compelling ontological and epistemological developments.

And in fact, when one begins to analyse the major works in the national historiography, it becomes apparent that, regardless of editorial context and, therefore, of the different methodological frameworks, the event was either simply forgotten ${ }^{5}$ or only mentioned in passing ${ }^{6}$.

On the other hand, with regard to the studies that devoted some space to this subject, it is important to distinguish between those included in general approaches, and those which are found in more specialized works of Military or Colonial History.

In the first category, we will begin by highlighting two relatively recent attempts to revive the study of Portuguese Expansion, História da Expansão Portuguesa, directed by Francisco Bethencourt and Kirti Chauduri, and A Nova História da Expansão, coordinated by Joel Serrão and A.H. Oliveira Marques. Both mention the defeat of the Ford of Pembe. In Volume IV of História da Expansão Portuguesa, Valentim Alexandre notes the

\footnotetext{
${ }^{5}$ As is the case in the following works: História de Portugal by A.H. Oliveira Marques, Nova História de Portugal, directed by the same author in partnership with Joel Serrão, Portugal Contemporâneo by Antonio Reis, História de Portugal, attributed to Jose Mattoso, and the recent História Contemporânea de Portugal, directed by Antonio Costa Pinto and Nuno Gonçalo Monteiro.

${ }^{6}$ See Damião Peres, who, in volume VII of the Monumental edition of his História de Portugal, in the chapter devoted to the Overseas Territories, in a total of 80 pages divided into four chapters, makes a single indirect reference to the Ford of Pembe when describing Alves Roçadas' appointment to conduct the campaign, following the debacle of 1904. João Medina, director of the História de Portugal, devotes two lines to the event in the chapter 'The military campaigns in Africa at the end of the century'. Joaquim Verissimo Serrão mentions the event in Vol. X of his História de Portugal, in a chapter suggestively titled 'A generation of Heroes', which highlights the figure of Lieutenant João Roby, one of the officers killed in Umpungo.
} 
importance of this expedition, underlining its objectives and number of troops while at the same time drawing attention to the impact of the outcome in Portugal?.

In vol. XI of Nova História da Expansão, Aida Freudenthal points to the 1904 defeat as an example of the permanent state of conflict which continued in the south until $1915^{8}$.

Neither case was an in-depth examination, but the methodological characteristics of both works, which focus on the problematization and broad contextualization of the facts, mean the problem is at least integrated into a whole, although it is never made clear that certain relevant breaks resulted from the dynamics of the event.

With regard to the second category, we must begin by saying that, as we were able to find numerous examples spanning a significant period of time, from the 1940s to the present day, the methodological perspectives we encountered were necessarily diverse, and follow the painstaking pace of innovation in the national historiography.

Thus, the incontrovertible work História do Exército Português by General Ferreira Martins is an example of a descriptive and traditionalist type of approach which, despite its obvious merits, could not resist describing the even from an uncritical, at times even slightly hagiographic perspective ${ }^{9}$.

More recent works, such as Nova História Militar, directed by Manuel Themudo Barata and Nuno Severiano Teixeira, or the encyclopaedia-type work História das Campanhas de Angola by René Pellisier, are not only more prolix in their examination of the subject, but also mark a sharp evolution in Military History, which is now interested in more than mere fact, description and biography, but nonetheless has no problem understanding that those dimensions must also be called upon to help build the great mosaic we call history.

The above-mentioned demonstrates the near-silencing of the event which the following may help shed a light on.

First, it appears that the more traditional outlook that dominated the Portuguese historiography until the mid-1960s, based primarily on the descriptive and biographical dimensions, while predisposed to factual and anecdotal analysis did not occupy itself with military defeats.

A second glance reveals that the painstaking process which renewed the Portuguese historiography over the twentieth century soon began to marginalize Military History, which was seen as a paradigm of the kind of traditionalism that must be overcome.

With regard to the first point, it is worth noting that during the Estado Novo, the very political environment, seeking the recognition of Portugal's specific claim to Africa both national and internationally, required the consolidation of certain forms of heroicity as a

\footnotetext{
${ }^{7}$ Bethencourt, 1998, p. 195.

8 Marques, 2001, p.274.

${ }^{9}$ Martins, 1945, pp.454/455.
} 
link to the country's mythological and apologist past of the sixteenth century, and allowed only the glorification of great deeds and military victories.

At the same time, we cannot fail to mention a fundamental cultural issue: the difficulties felt by the Portuguese intelligentsia in overcoming the nineteenth century perceptions of 'the negro'. This meant that, well into the twentieth century, the indigenous populations were still seen as children in need of protection, or worse, like wild, brute savages.

At the same time, the 'imperialist' discourse gained an adjectival dimension, without any substantive developments. That is, while it is true that, in the words of Margarida Calafate, 'all empires are largely imaginary or political fictions by nations that exceed themselves ${ }^{10}$ in the Portuguese case this schizophrenia is manifested in a difficulty to accept any evidence of weakness.

To accept, even if through analysis and reflection, a military defeat against indigenous populations was to call into question the country's perceived image of superiority, which was also needed to justify the national discourses of power assertion.

With regard to the second point, the historiographic renewal movements can be said to have been marked from birth by their distrust of the military. The currents inspired by the Annales School called for the suppression of the individual, of the exclusive appreciation of top leadership and of all that was factual and descriptive, thus calling into question everything that had characterized Military History until that moment.

Portugal was, in any event, slow to accept these principles, but they were still enough to exile military historiography from the academic domain, and it became a hunting ground of sorts for military scholars and training spaces.

In recent decades, a set of individual and even institutional initiatives began to reverse the situation, renewing Military History by abandoning its propagandistic dimension and endowing it with ontological scope. However, paradoxically, and because it was marked by the preponderance of more traditional views, the 'battle' dimension has not been significantly reclaimed as a privileged object of study.

The strategic studies on the daily lives of soldiers and on military technology and culture have increased, but the same cannot be said of war itself.

It seems clear that the study of war cannot be circumscribed to military perspectives, especially if that implies forgetting the impact that war, due to its capacity for destruction, has on the social whole. War transfigures social norms, alters landscapes, has an impact on culture, economy and politics, and all these aspects must be studied, but at the same time the actual battle should not be disregarded, and one should instead attempt to understand its specific dynamics, structures and developments. This awareness is keenly felt in Anglo-Saxon historiography, but has been rather absent from many of the

${ }^{10}$ Calafate, 2004, p. 122. 
evolutionary leaps in Portuguese historiography and is thus another possible reason for the silencing of Pembe.

\section{Social and political impact}

Posterity may have had little to say about Pembe, but the same cannot be said of its contemporaries. In fact, each new report from Africa sent major shockwaves throughout several levels of society. Multiple solidarity actions and religious ceremonies were held all across the country, while the press issued opinion pieces, interviews and news reports, and the parliament began an intense political discussion that lasted until the fall of the Regenerator government of Hintze Ribeiro.

\section{Social impact}

With regard to this dimension, it should be clarified from the outset that the adherence of the Portuguese society to the African imperial project during the nineteenth century was far from unanimous. For the overwhelming majority of the population, Africa was a land of exiles, disease and ill-fortune, and the reports of defeats, which were indeed abundant, did not cause any stir, unless in very exceptional situations such as the death of the Count of Almoster in the third Humbe revolt, in 1897.

On the other hand, in intellectual circles the opinions were markedly divided. For some, the path of Africa, justified as it was by the often mythologized heritage of the glorious past of the discoveries, clearly converged with a Europe with newly acquired colonial ambitions, and from which Portugal felt increasingly isolated; for others, on the contrary, colonization was seen as a sign of national decay, and the sale of the African territories seemed to them a reasonable solution ${ }^{11}$.

Meanwhile, the impact caused by the British ultimatum and the changes in the international political system did not fundamentally alter the above circumstances, but still stirred feelings of patriotism and, most of all, contributed to a certain kind of loftiness in the perceptions of Africa, which escalated the construction process of a colonialist ideology.

This resulted in an obvious attempt at power projection by 'manus militaris ', through the so-called pacification campaigns, which were no more than effective actions of occupation to consolidate a new ruling order. This paved the way for the iconic military victories of the late nineteenth century in Mozambique, specifically Marracuene, Magul, Coolela and Mandlakazi, but also in Angola, in Bailundo and Humbe, already in the early twentieth century. These victories were magnified by the press and transformed into near-

\footnotetext{
${ }^{11}$ See, for example, Antero in Causas da Decadência dos Povos Peninsulares or Eça in Farpas.
} 
mythological symbols, generating a triumphalist feeling in the country and bringing glory to a new generation of soldiers, who were praised in the mainland, where they were greeted by the king, decorated and celebrated.

Thus, Africa was increasingly seen as the stage where the country would be redeemed and as an opportunity to gain recognition in the concert of nations, hence the defeat of 1904 constituted a violent clash with reality and caused widespread waves of discontent. The first news was met with bemusement in Moçâmedes. The initial reports had supposedly arrived at dawn, on 26 September, but it was only on the 28th that they began to spread, to great commotion and upheaval. Several symbolic measures were immediately taken, such as a ban on playing music on the main street and public donation campaigns set up for widows and orphans.

At the same time, in the major metropolitan newspapers a highly critical discourse began to circulate against the Lisbon government and the expedition commander, who was held fully accountable for the defeat. In the mainland, newspapers from all over the country, which until that moment had been far more concerned with the Russo-Japanese War, began to turn their attention to the woeful events of southern Angola. Opinion pieces were published daily, mainly by newspapers Diário de Noticias (DN) and O Século, and there was constant coverage of the political and social impact of the event.

At the same time, motivated by the lack of official reports, hundreds of people occupied the Navy Ministry on 5 October, demanding the release of the official casualties list, which, rumour had it, existed somewhere in that institution. According to the $D N^{12}$, Minister Raphael Gorjão issued an order to divulge the list of military casualties, then later regretted it and issued a counter-order. The official comprehensive list of the dead was only published on 10 October, although on the 6th, the $D N$ had already published the names and biographical data of the dead officers and sergeants on the front page ${ }^{13}$.

At the same time, both official and private manifestations of grief multiplied and Masses for the repose of the dead were held all over the country ${ }^{14}$. On 13 October, official funeral rites in honour of the dead soldiers were held in the Church of São Domingos. The obsequies were attended by King Carlos, Prince Afonso, virtually the entire government and diplomatic corps, and a large audience that had gathered in the square in front of the temple since the early hours of the morning, filling it to capacity.

\footnotetext{
12 Diário de Noticias, 6 October 1904, p.1.

${ }^{13}$ On the 10th, issue 49 of the magazine Ilustração Portuguesa also published photos of nearly every dead officer. On the 16th, issue 138 of the Brasil-Portugal magazine and, on the 20th, issue 929 of the magazine $O$ Ocidente published photos of thirteen officers fallen in Pembe on the front page.

${ }_{14}$ We found mention of religious celebrations for the repose of the victims of the Ford of Pembe in such places as Almada, Aveiro, Barcelos, Beja, Braga, Cascais, Coimbra, Ferreira do Zêzere, Leiria, Mafra, Moçâmedes, Oliveira do Bairro, Paço de Arcos, Paredes, Silves, Torres Novas.
} 


\section{Political impact}

In terms of politics, the impact of the debacle of the Ford of Pembe translated into a heated political debate in both houses of Parliament. In the House of Representatives, there was a breach in the customary consensus between the two major parties (the Regenerator Party, in power at the time, and the progressive party, the opposition) in matters of foreign policy or public order. On 4 October, the Secretary of the Navy, Raphael Gorjão, interrupted the $2^{\text {nd }}$ session of the $2^{\text {nd }}$ parliamentary sitting of the House of Representatives to announce the defeat of Captain Pinto de Almeida's troops, and the opposition members initiated a ten-day debate during which they attempted to exploit the commotion that was spreading across the country as reports from official sources in Angola confirmed the size of the defeat.

In the House of Representatives, the discussion centred on political accountability, and the conduct of operations on the ground or the conduct of the men in the campaign was never called into question. On the contrary, great lengths were taken to extol the heroic qualities of the Portuguese military, who were completely exonerated from any blame. The two major issues under discussion can be summarized into two levels. On the one hand, there was the immediate issue of how the reports had been managed by the Regenerator cabinet and, on the other, there were the issues directly related to the military actions under discussion.

At first, the ministerial cabinet was reprimanded for failing to formally inform the nation until 4 October, as it was common knowledge that the first telegrams with news from Moçâmedes had arrived in Lisbon on 26 September. The second level concerns the subsequent demands to clarify the mission objectives, composition, troops and weapons. With regard to objectives, there was no significant challenge from the progressives, because in their opinion, the crux of the problem lay in what they considered to be an insufficient number of men mobilized for the campaign and in the scarce, and especially defective, warfare equipment provided to the troops. Concerning the latter, the emphasis was placed, in particular, on the ammunition distributed to Pinto de Almeida's detachment, which was thought to be insufficient.

Simultaneously, in the House of Peers, the interventions from the opposition were led by Generals Dantas Barracho and Sebastião Telles, and also by Aires de Ornelas, who echoed the concerns of the other house of parliament by addressing more technical issues, and therefore began analysing the conduct of operations. One such issue was the very leadership of the expedition, as the choice of captain was considered inadequate, especially when there were other soldiers in the expedition who held the same rank and also had seniority. While this is a significant issue which concerns the unique dynamics of military communities, it will only be briefly mentioned here, as the decisive factor for the 
outcome of operations is considered to be the model of offensive detachment adopted. The 'Provisional Instructions for Field Service in Africa', written in 1896 by Eduardo Costa and used by Mouzinho in the Mozambique campaigns, stated that reconnaissance should be carried out by cavalry patrols and small groups of highly mobile indigenous auxiliaries. In view of the above, Aires de Ornelas declared that a lack of respect for these principles, which were by then considered doctrine, had been one of the reasons for the failure of the expedition. Ornelas added that he found it difficult to understand the use of a detachment like Pinto de Almeida's, which at almost five hundred soldiers seemed at once wholly inadequate to reconnaissance actions and too small to progress safely on the ground, an assumption which the events in Pembe confirmed.

In the face of this criticism, the Secretary of the Navy and the Chief of Staff, Hintze Ribeiro, attended the session of the House of Representatives on 13 October and defended themselves by claiming that this kind of outcome was always possible in situations of warfare, and although the rhetoric employed by both men implied an acceptance of responsibility, they effectively rejected any charges. Both men also claimed that all the resources requested by the commander had been made available for the expedition and that equipment and troop reinforcements were also provided during the preparation phase, already on the ground, some of which were even rejected, as they were deemed unnecessary by João Maria de Aguiar.

This climate of parliamentary tension did not last for long. Soon, other more pressing domestic policy issues came to the forefront, as was the case of the 'tobacco issue', which eventually even led to yet another fall of a Hintze government and another return to power by José Luciano, who was by then physically fragile, in another episode of what João Franco, in 1900, dubbed major party rotativism.

\section{The causes for the fiasco}

The discussion generated by the Pembe debacle in various platforms for debate - the press, the parliament, and the military circles - demanded to know at once what had caused the defeat. Four fundamental issues constituted the guiding foci of the discussion: the objectives, the human and material assets, the campaign preparation, and the tactical framework. Let us examine at some length the discussion around each item.

\section{The Objectives}

The political objectives 
There was never any major controversy around the objectives that shaped the 1904 expedition, neither in the context of the attempts to politically exploit the consequences of the debacle, nor in the military circles where the event was discussed.

This state of affairs stemmed from an apparent platform of consensus regarding the policy for Africa.

That platform, which we call consensual - aware, however, that 'consensual' does not stand for 'unanimous' -, was essentially driven by the desire to ensure, using as little resources as possible, the continuity of a policy, and especially of a discourse which, shaped as it was by the trauma of the ultimatum, called for the consolidation of practices that, while not assuring a truly effective occupation, were justified by that objective. From the above we may then draw two dimensions. One is related to what we will refer to as domestic policy, for reasons of convenience, and another concerns the international dimensions of the policy of the final phase of the constitutional monarchy. On the domestic level, it was imperative to consolidate mechanisms of sovereignty over the African peoples; internationally, it was necessary to take a stance on the perceived German ambitions for southern Angola.

With regard to the first dimension, we must begin by noting that the sovereign mechanisms of influence were far from being consolidated in the region. The exercise of national power was sparse and inadequate in the area west of the Cunene River, and thus was continuously under threat by the Ovampos peoples (mainly the Kwamatos and the Kwanyama), who resisted any form of taxation, often attacking the scattered nuclei of white settlers and their respective economic interests. Externally, since 1870, a new international reality had emerged from the collapse of British hegemony and the emergence of other powers (particularly Germany), which claimed significant portions of colonial rule, leading Portugal to undertake material and ideological efforts to consolidate the colonial Africanist discourse under construction.

In the aftermath of the 1898 agreement between Britain and Germany ${ }^{15}$ and of the issue of the definition of borders between Angola and the German colony of South West Africa ${ }^{16}$, Lisbon had glimpsed the German ambitions and found them a clear danger to its interests. Furthermore, in 1904, in South West Africa, General Von Trotha defeated the uprising of the Hereros, who had been on the run since then, but concerns were raised that these peoples may have crossed the border to Angolan territory, or, on the other

\footnotetext{
15 Distressed by the declaration of bankruptcy in 1892, the Portuguese government considered obtaining a loan from England, with the revenues from the colonial customs as collateral. Aware of this possibility, Germany, whose colonial ambitions had been awakened, approached London, which was interested in the proposal and agreed to share the customs revenues of the Portuguese colonies, while ensuring that a failure to pay by Portugal would imply the partition of the spheres of influence of those customs between Germany and England. Aware of the agreement, Portugal did not accept the loan.

${ }^{16}$ See Convénio Barros Gomes-Schhmitzals, 1886 - Arquivo Histórico Militar- P.2 - M.31 Processo 34.
} 
hand, that the German army on their trail could effectively occupy territories Lisbon regarded as belonging to Portugal. Thus, in 1904, the circles of power defined clear and ultimately unanimous strategic objectives: it was necessary to break the resistance of the Ovampos and to unequivocally affirm Portugal's claims over those regions of southern Angola.

It is worth noting, however, that the above-mentioned consensus began to crumble when the discussion moved from the great purposes of the State to the use of resources on the ground. That is, there may have been an agreement on what objectives to accomplish, but the same was not true of how those objectives were to be accomplished. Essentially, this meant that it was imperative to discuss the fiscal issue. Let us begin by stating that Portugal was the European country with the largest proportional allocation of resources to an overseas policy, and that military expenditure in particular was always deeply regretted, leading many to call for financially less demanding processes of affirmation of sovereignty, such as the advancement of trade networks, the action of religious missions or even the use of diplomacy as a rapprochement strategy.

The Africanist military circles were convinced, however, that political objectives could only be achieved with an increase in military spending. In their opinion, the instability in the south, the lack of penetration on the ground and the irreverence of the Ovampos peoples demonstrated the need for military occupation as the sole guarantor of an effective ownership claim. Therefore, they advocated the need for rapid progress in the hinterland in order to reach the borders that had been established in the international agreements and to consolidate an effective presence there. Their recommendation was to exploit the existing communication routes while simultaneously occupying that line of penetration with military outposts to ensure not only the protection of said communication routes, but also to serve as power projection centres to implement sovereignty mechanisms over the indigenous peoples.

In other words, there was a call for the systematic occupation of territory by occupying strategic points and projecting successive sovereignty operations from those points, penalising the economic interests of indigenous peoples and maintaining constant surveillance, which meant breaking with the common practice of withdrawing the troops after defeating the insurrectionist peoples. This required highly mobile military columns, and at the same time forts had to be built and subsequently garrisoned with wellequipped units, which required the allocation of financial resources that, in the early twentieth century, the government could not afford.

It should be noted that the resistance to the increase of expenditure in Africa did not imply a simple schism between the military and political spheres, and that the situation was far more complex, as the Africanist stance had managed to garner a fair measure of support from certain political sectors, particularly the opposition, while at the same time it 
caused revulsion in certain sectors of the Army, for whom defending restraint in the overseas fiscal policy was a way to avert negative effects on the structural reform of the mainland system of forces, which they considered more urgent.

In fact, this dichotomy was ever present until the beginning of the Great War. On the one hand, there were those for whom successfully achieving defined objectives required greater budgetary allocation, while there were others who considered curtailing the expenditure for Africa a priority.

It should be noted, merely as an example, that the immediate result of the commotion caused by the events in Pembe was a general impulse to organize a punitive expedition, while at the same time a committee was appointed to conduct a survey of new armament for future overseas operations and Eduardo da Costa ${ }^{17}$ was asked to develop an operations project for the insurrectionist regions. However, fiscal restraint was eventually given priority over all these projects. The punitive expedition was delayed for several years; the proposal of the armament committee to replace all the Sniders used by indigenous troops with Martini-Henry rifles was never fully developed and Eduardo da Costa's plan was considered impractical because both the number of human resources and the budget it required from the kingdom, 1884 contos, were deemed excessive.

\section{Operational objectives}

The political objectives resulted in the orders issued by the Lisbon Government for the campaign against the Kwanyama in June 1904. The main objective defined at the time was the effective control of the entire region between the Cunene and Cubango rivers, and the occupation of Ngiva, the embala ${ }^{18}$ of the Kwanyama soba, was deemed imperative to achieve that purpose. One month later, on 16 July, Custódio Borja, Governor-General of Angola, sent his orders to the expedition commander. In those orders, he reiterated Ngiva as the main objective, and also stated the need to defeat the Kwamatos and to set up military outposts on the border with the German colony. These instructions resulted in the operational objectives defined by João Maria de Aguiar: the occupation of Mogogo (the capital of Little Kwamato) and Ngiva (the Kwanyama capital) ${ }^{19}$.

\footnotetext{
${ }^{17}$ A distinguished Africanist, who had been Governor of the districts of Mozambique and Benguela and acting Governor-General of Angola, where he would even become Governor-General between 1906 and 1907.

${ }^{18}$ The capitals of the Soba territories.

19 The marching order for the column which, on the 19th, left the Humbe towards the Ford of Pembe, definitively states: 'the column will march tomorrow on Moghogho, the embala of the Kwamato soba, to defeat the natives of this region and of the Kwanhama'.
} 
After the tragic events of September, the choices made by the expedition commander were enthusiastically discussed in certain circles with the following arguments: first, as the Kwanyama were considered the main opponents to Portuguese sovereignty, it was argued that the advances should have been made directly on their embala, thus avoiding a direct confrontation with the Kwamatos; on the other hand, the decision to cross the Cunene at the Ford of Pembe was contested. The arguments put forth to support the second premise were based on the fact that Pembe was located 30Km from Mogogo and 50Km from Ngiva, and that it was difficult to cover those distances, since the process was only put into motion late in the year. The rain season was approaching and, from that moment on, the progression of troops on the ground was non-existent, as the paths were flooded and impracticable.

In the end, none of the above was considered crucial to the events of 25 September, which led to this kind of thinking being deemed somewhat irrelevant to the discursive strategy of those who intended to hold the operational command exclusively accountable. Nevertheless, these arguments were highly criticised in a group of editorial pieces in both the $D N$ and $O$ Século, and also appear in several interviews that certain military individuals anonymously granted those agents of the press.

These communication strategies may have implied a rather hostile attitude toward the expedition commander, but they also resulted in counter-arguments which attempted to justify the choices made by João Maria de Aguiar, not least because they considered that personifying the blame tended to exonerate the underlying power structures, which were thus acquitted of their potential liability.

Two fundamental ideas can be briefly identified in the latter discourse. On the one hand, some claimed that the objectives defined by command were well within the political objectives determined by the upper echelons, as well as within the usual combat practices in Africa. On the other, some defended the idea that the campaign had not been initiated too late, as the advance on Ngiva was only scheduled for 1905 . The first argument, which was later used by João Maria de Aguiar himself, was initially used by military officers with African experience, who, while expressing a degree of confusion at certain aspects of the tactical framework employed, also wished to clarify that, in the African campaigns, the military objectives defined were usually the occupation of the dwellings of the peoples one wished to conquer, and not a direct confrontation with enemy armies.

In fact, combat experience in the outback had made it clear that, as a rule, the conquest of the soba capitals resulted in a disorganized rout by the indigenous populations. Indeed, the occupation of Mogogo and Ngiva made perfect sense if the objective was to dismantle the resistance of those peoples. On the other hand, the preference for facing the Kwamatos first, and only then the Kwanyama, can be explained by the ever-present fear of a possible extended alliance between the Ovampos peoples, and the belief that the 
Kwamatos would be easier to defeat, after which the Kwanyama could be convinced to surrender through diplomatic channels.

The second argument, which gained special visibility with the studies by Colonel Genipro de Almeida ${ }^{20}$, is more debatable, because it contradicts the very order of the operations of 19 September, which expressly stated the immediate objective of advancing on Kwanhama. In any event, it is also a fact that an analysis of the memoirs and diaries of some of the deployed troops revealed general uncertainty about the objectives. Apparently, during the days when the troops remained stationed in the bank of the Cunene River, is was not generally known if the intentions of the command were to station the troops and build an outpost that would function as centre of operations for an initiative to be carried out the following year or, rather, if the intention was to advance on Mogogo, or even on Ngiva right from the beginning.

As the few surviving memoirs and diaries were written mainly by officers, this indecision is a source of bemusement, and it points to a failure of communication between Aguiar and his General-Staff, one of the problems thought to have had a major influence on the conduct of operations ${ }^{21}$.

\section{The resources}

The issues related to the resources available for deployment were at the centre of the discussion on the causes of the debacle. The human assets were called into question, with some thinking them insufficient and others, poorly prepared. The armament was also discussed, whether it was old or modern, and whether ammunition was insufficient or more than enough. There was no lack of opinions and controversy, and many were politically motivated and at times contaminated by ulterior motives, petty hatreds and acute rivalries. It is thus understandable if nothing conclusive can be drawn from the above. In any case, let us try.

\section{Human resources}

In this respect, we must separate the parliamentary opposition's criticism of the government and the criticism directly addressed to the expedition commander. In the first case, the Regenerator cabinet was accused of providing a small, heterogeneous

\footnotetext{
${ }^{20}$ Almeida, 1927.

${ }^{21}$ Several of the officers had seniority and were more experienced in African campaigns than Aguiar, and therefore did not willingly accept his authority. Ex-officio, governors, even when they were not soldiers, commanded the expeditions in which they participated.
} 
contingent, poorly prepared in the most basic principles of military education. In the second case, Captain Aguiar was accused of rejecting the Governor-General's offer of 400 auxiliary troops while still in Luanda and of recruiting only 100 Muximba auxiliaries on the plateau, where he could have conducted an expanded recruitment of indigenous auxiliaries.

As for the charges put forth by the parliament, it must be noted, first, that the criticism focusing on the insufficient troops in the column rested mainly on the conviction that certain information coming from Angola was true, namely that which attributed a recruitment capacity of over twenty thousand warriors to the enemy ${ }^{22}$.

However, the sources are not in agreement, neither with regard to the total numbers in the expedition, with different numbers appearing even in the memoirs of some of the expeditionary soldiers ${ }^{23}$, nor in relation to the indigenous recruitment capabilities ${ }^{24}$. In any event, the collated sources led us to believe that the estimated total number of men in the march to Pembe, approximately between 1800 and 2000, was not very far from the truth.

As for the Kwamatos, who fought against the column during those fateful days in September, and in particular against the ill-fated detachment of Pinto de Almeida, it is virtually impossible to make an estimate that does not raise multiple questions ${ }^{25}$. However, contemporary criticism stemmed from assumptions which must be considered in the light of the following observations. First, the European armies in Africa traditionally fought outnumbered, exploiting their tactical and logistical superiority ${ }^{26}$. Second, the difficulties in securing communications, food and transportation did not normally allow for

\footnotetext{
22 In July 1904, the newspaper Correio de Mossâmedes reported that a possible alliance of Ovampos peoples could gather as many as 30,000 men.

${ }^{23}$ Contreiras Junior speaks of 1800 men, including regular and irregular troops (Contreiras Junior, 1937, p.7), Salgado reports 2053, including 519 Europeans (Caldeira, 2011), and more recent authors, like Jaime Ferreira Regalado, reiterate the number of 1800 men and specify that, of those, 500 were European (Regalado, 2004, p.15); René Pelissier speaks of a total of 1160, of which 507 were Europeans (Pélissier 1986). On 25 August, the $D N$ mentions 2200 soldiers but a letter from the correspondent in Moçâmedes, on 22 September, which was published on October 14, mentions 2000 men. In a report from 1927, Genipro Almeida states that, upon the departure from Lubango, the expedition had 1223 men, of which 493 were indigenous auxiliaries. In Humbe, the column was reinforced with the 15th and 16th indigenous companies, reaching a total 2030 men, of which 199 from the 15th company did not initially advance to Pembe. According to these figures, the full expedition which progressed to the Cunene counted a total of 1831 men. ${ }^{24}$ Eduardo da Costa (1906 pp. 22-24) presents a summary of known calculations before 1904, where a possible coalition of Ovampos peoples is presented with wildly different potential numbers; some attribute 20,000 men to the coalition, while others speak of 50,000 men, although regarding the Kwamatos alone, the projections never exceed 15,000, with 10,000 being the number mentioned most often.

${ }^{25}$ Contreiras Junior $(1937$, p.33) mentions the great superiority of the enemy, in a proportion of 30 or 40 to 1.

${ }^{26}$ According to Eduardo Costa (Costa, 1896, p. 78), the troops in Marracuene fought in a ratio of 1 to 4 , in Magul, of 1 to 24, and in Coolela, of 1 to 20.
} 
large expeditions. Third, in the Umpungo battle, it was not the bulk of the column that was massacred, but only an offensive detachment, and thus it cannot be said that the defeat resulted from a lack of manpower for the expedition, but possibly from the division of the force.

In turn, the criticism regarding the heterogeneity of the troops stemmed from a negative view of the men forming the disciplinary battalion, which was composed of deserters and convicted criminals ${ }^{27}$, and of the high numbers of indigenous conscripts, approximately 1300 to 1500 , which greatly exceeded $50 \%$ of the troops. Many now recall the victorious campaign of 1895, in Mozambique, where not only were the latest technology, the most current tactics and the most appropriate logistical procedures employed, but the bulk of the military troops on the ground were forces from the mainland. Either way, the discussion on the use of indigenous troops was marked by highly contradictory views which expressed strong ideological positions and went beyond simply discussing this particular conflict. Indeed, the arguments of those who considered the use of indigenous elements excessive often reached discursive levels closely derived from the principles of Social Darwinism. The 'negro' was considered a brute, with limited capacity for learning, and, when armed, dangerous for white people.

However, the critics could not deny the usefulness of indigenous troops for the African campaigns, and understood that they brought undeniable advantages from the outset, first for the abundant resources they provided and also for their greater ability to adapt to the climate and geographical reality, which Europeans found rather punishing. However, in their opinion, these advantages could only be used to their full potential if the natives were given a frame of behaviour by a competent white leader, as they argued had occurred in Mozambique, but not in Angola. Many of these criticisms must also be understood in a broader context of opposition to the military reorganization of 1901 . The reorganization aimed to avoid resorting to expensive metropolitan expeditions, which often had to be mobilized to contain the constant indigenous uprisings, by creating a set of legal mechanisms to promote the employment of indigenous troops, specifically by training indigenous infantry and mixed artillery companies.

At the same time, troops had to be deployed from the mainland, as the overseas army seemed incapable of performing what should have been its core mission - to secure an effective occupation, to enforce territorial integrity, to keep the peace and to protect economic activity -, thus calling for a reorganization ${ }^{28}$. For that end, the two armies would

\footnotetext{
27 The disciplinary detachments left a negative impression still in Lubango by robbing commercial establishments and defecting with the product of said robbery but, in fairness, their combat actions demonstrated bravery and were thus highly praised in all the official reports and memories analysed.

${ }^{28}$ Decreto da Secretaria dos Negócios da Guerra, November 14, 1901, in Ordem do Exército n.o 17, p. 377.
} 
remain active, one in the mainland and one overseas ${ }^{29}$, with the latter operating under the Navy and Overseas ministries, but a number of mechanisms would be introduced to facilitate the transport of European troops to Africa, namely: promotion for volunteers who, upon their return the kingdom, would have to be admitted to the access roster of their respective arms, bonuses for time served, better salary conditions and gratifications. However, in practice these mechanisms met with a degree of resentment from those who did not want to leave for the colonies and who considered that the periodic deployment of troops overseas divided the army of the kingdom without any advantage for the overseas army, because those deployed seldom remained in Africa once they had completed their commission and received the respective promotion.

Many of the provisions set out in 1901 would be altered, some would never be applied and, for the great part, the indigenous companies that were formed were eventually extinct before 1910. But the truth remains that, in 1904, the criticism generated by this reform was intense and mobilizing, and it also provided a context for the criticism of the indigenous soldiers employed in Pembe. As for the technical training of the troops involved in this campaign, it cannot be denied that it was highly precarious and rudimentary and in accordance with the levels of illiteracy in the Portuguese society of the time. With regard to the forces sent from the mainland, we must begin by separating the officers from the remaining contingent. While it is true that the educational levels of the first were highly diverse, all had undergone basic training far beyond what was then considered normal. However, they had no specific training regarding colonial matters, and there was a lack of soldiers with training in more technical areas, such as engineers or sappers.

At the same time, the few officers in this campaign with experience in Africa had acquired it in Mozambique and not in Angola, and this would eventually prove a significant factor, as they did not demonstrate the insight needed to tailor their Mozambican experience to the realities of the west coast, which was considerably different in some respects. On the other hand, and due to the policy of promotions defined in the reorganization of 1901, many of the Ensigns in the expedition were actually Sergeants in the army of the kingdom, who, unjustly or not, were accused of not having the required technical expertise or leadership skills to properly enhance the indigenous capabilities. Regarding the enlisted, the vast majority were reservists who were not only illiterate, but were also ill-prepared in military terms ${ }^{30}$.

As for the indigenous troops, on the one hand, their adaptability to the harsh terrain and climate was an important asset; on the other, they generally showed serious training

\footnotetext{
${ }^{29}$ The organic division between the overseas and colonial armies lasted until 1926, when the private staff was extinct.

30 Still in Lisbon, these troops had to be given some rudimentary training at the level of drill commands, so they could present before the king at the farewell ceremony.
} 
deficiencies, which in many cases could be resolved, if properly addressed, but in others, as was the case with shooting skills, were not as easy to overcome. In this regard, Bartolomeu Paiva, commander of the Muximba auxiliaries, said in an interview with Diário de Noticias: 'The blacks almost did not know how to shoot a weapon. The Kwamatos would have had to fly in order to be hit.... One day, when the Kwamatos came within 40 meters of the camp, a group of soldiers received them with a salvo. Well, not one black dropped to the ground ${ }^{31}$.

To be fair, the march between Lubango and Humbe was spent providing the soldiers with intensive training on combat tactics, rapid transition from marching formation to square formation, field service, protection on the move and stationary protection, setting up and dismantling a bivouac, firing discipline and practice in the shooting range. But it is not hard to accept that this training may have proven insufficient.

\section{Material resources}

Where armament was concerned, the criticism arising from the analysis of the Pembe campaign had focused on the idea of political and technical incompetence. The first was revealed in the alleged neglect by the government in terms of supply of weapons and ammunition, and the second in the lack of inspection by the commander, who supposedly did not investigate the quality of the weapons distributed, and whose estimate of the total ammunition needed was also inadequate.

Regarding the first argument, in which the progressive opposition based many of their parliamentary interventions, it should be noted that on 11 May, still during the preparation phase of the expedition, Governor-General Custódio Borja sent the following telegram to Lisbon: 'The service weapon of the indigenous units, which has been traditionally used in this province, is an old Snider rifle with all its ballistic features completely absent. The cartridge provisions are partly deteriorated and are also untrustworthy, which is where the Snider's flaws become evident as a weapon of choice for the troops of this province... ${ }^{32}$.

There was no reply to the telegram. But three months later, minister Gorjão, concerned with the news reports that attributed to the Kwanyama a wealth of human assets armed with over 200 improved firearms, asked Borja to consult with Aguiar regarding a possible need for reinforcements. João Maria de Aguiar replied in a telegram on 15 August that nothing was required because he had all the resources he needed. This reply was often used by the Secretary of the Navy in the parliamentary discussions of October to justify his statement that all the resources requested by the expedition had been provided.

${ }^{31} D N, 5$ December 1904, p. 3.

${ }^{32} \mathrm{AHM} / 2 / 2 / 9 / 7$. 
In fact, the armament of the troops upon leaving Lubango appears to have been perfectly suited to the expected characteristics of the operation ${ }^{33}$, particularly to ensure an effective technological superiority over the Ovampos. In fact, despite it being common knowledge that the indigenous troops acquired arms and ammunition from Portuguese and German merchants, and especially from missionaries, their logistic capabilities were not accurately known ${ }^{34}$. However, it seems clear that much of the information disseminated on the military capabilities of the indigenous troops was intentionally inflated as a strategy to request more resources, so it seems that the opinion of the Huila governor was essentially well-adjusted, in the sense that the Kwamatos were not likely to be on any kind of equal footing with the national forces.

Concerning the quality of the weapons, it must be remembered that it was common practice to send weapons that were no longer in use by the army of the kingdom to the colonies, and while this never led to any significant issues in terms of technological superiority, it sometimes led to tactical embarrassments. As older weapons were sent from the mainland, the local authorities were able to acquire more advanced weapons in South Africa, which meant the columns often appeared in combat armed with very different weaponry, sometimes from different generations, and it was common, as seen in the battle of the Ford of Pembe, to see some soldiers armed with repeating rifles, while others fought with older carbines and repeating rifles.

Since the Portuguese forces fired on command, in continuous fire, this meant it was impossible for all the soldiers to shoot at the same time, something which could have very negative consequences for little disciplined and ill-prepared troops.

Regarding the criticism directed at the commander of the column and his alleged negligence in relation to the inspection of the readiness of the equipment and his poor calculation of ammunition needs, it should be noted that during the fighting, many of the Sniders used by the indigenous troops were found to have been seriously defective. A few were missing the rear sight, in others there was no front sight and the hammer did not work, and many even jammed after heating up. However, the poor quality of many of these rifles had not only been previously diagnosed but had been reported to the higher echelons in May, so the attempt to assign responsibility to the expedition commander appears to have been somewhat forced.

The issue of ammunition is somewhat more complex. During the combat of the 25th, and after an hour of disciplined fire on command, many soldiers began to shoot freely, which turned out to be a decisive factor in the depletion of ammunition on one of the faces of

${ }^{33}$ Kropatscheck repetition rifles, Snider rifles and carbines, eight $7 \mathrm{~cm}$ pieces. BEM (Bronze, Striated, Mountain) pieces, 4 Hotckiss heavy machine guns and 1 Nordenfeldt machine gun.

${ }^{34}$ The information that was disseminated was rather contradictory; some mentioned 5000 warriors armed with Martini-Henry rifles, others went as far as to claim that the indigenous troops owned Mausers, which even the mainland army only began to use in 1905. 
the square, forcing a charge with bladed weapons, and there the indigenous troops were clearly superior. In the marching orders published in Humbe on 18 September, the last day the troops were stationed before the march toward Pembe, the ammunition allocated to each Infantry enlisted stood at 120 cartridges, although many would later state that, during the Umpungo combat, soldiers had no more than 10 cartridges each. These allegations cannot be confirmed, and in fact large quantities of ammunition were stored in the bivouac next to the river which, for reasons unknown, was not distributed to Pinto de Almeida's detachment. Thus, it seems clear that there was a serious flaw, but one that, however, can only marginally be attributed to the expedition commander as the ultimate responsible for operations, because the inspection of the ammunition distributed to the soldiers does not appear to have been a direct attribution of his duties.

\section{The tactics}

The doctrinal framework for overseas military action was based primarily on the Provisional Instructions for Field Service in Africa. In this document, Eduardo da Costa, in an update to the Provisional Regulations for the Army Service in the Field, provided instructions for colonial operations in terms of reconnaissance, information, marching, stationing and combat. This work was of significant importance, as it provided the basis for many of the most important campaigns in Mozambique in the late nineteenth century and it was responsible for the adoption of the square formation in the marching and fighting tactics employed in the colonial campaigns.

This tactic, which had worked well in the fights with the Vatwa, had some limitations when facing opponents with different types of strategies, as indeed happened in Mozambique, in the Namarrais campaign. The Vatwa preferred fighting in open field, en masse, while attempting to envelop the opponent, therefore an army with superior armament could form in square and then only had to hold position and resist until the opponent was defeated by the heavy losses inflicted. The Kwamatos, on the other hand, used tactical gear, camouflaged themselves in the vegetation or took advantage of other subterfuges such as the termite hills in southern Angola. They hid behind tree trunks and other obstacles, firing from a covered position and without taking major risks, and only when the circumstances were favourable. They aimed at the officers and the solidungulates, wearing down the Portuguese forces physically and morally and trying to provoke them into excessive consumption of ammunition. Once the enemy was fatigued and worn down by the casualties, if the Kwamatos sensed that the ammunition had been depleted, they attacked with a clear advantage, looking for close combat with bladed weapons, in which they were superior. Thus, under these conditions, the square, if it was even formed, should have the ability to scatter quickly, so that after the preparatory 
artillery action a decisive assault could be launched on the enemy, who was expected to retreat even with superior numbers.

In the case of the Ford of Pembe, captain Pinto de Almeida, who had combat experience in Mozambique but not in Angola, chose to hold the square for an hour, which caused the ammunition to be depleted and allowed the Kwamatos to attack, breaching one of the faces of the square and spreading panic in the column, leading to a late and disorderly retreat. Indeed, two offensive actions were launched during the period when the troops formed in square were under enemy fire, neither very successful. One of those actions was carried out by the Dragoons, which were not the most suitable unit for overgrown woodland areas, as the indigenous troops, protected behind the trees and vegetation, fired on the riders and their mounts, which in turn were advancing 'blind'. The squadron commander was killed during this operation and the Dragons retreated to the square. The other initiative was carried out by a platoon of disciplinary troops, which successfully occupied an area at the edge of the woods. Later, inexplicably, Almeida Pinto issued orders to regroup, allowing the Kwamatos to return, regroup and subsequently attack the square en masse.

Thus, it seems that although the long-term stationing on the banks of the Cunene and the division of forces proved to be controversial options, it was the misuse of the square formation that was critical to the defeat, as, in an attempt to repeat the success in Mozambique, the square remained fixed for over an hour, responding with heavy fire to enemy attacks. This allowed the Kwamatos to deplete the ammunition of the Portuguese troops and then launch a final decisive counterattack, breaching the square.

\section{CONCLUSION}

Fear, anger and shame, the formula found by José Eduardo Agualusa to describe the events in the banks of the Cunene on 25 September 1904, appears to be an accurate summary of what happened on that day. Clearly, this reading is largely a reflection of a creative reinterpretation of events, but the fact remains that several situations allowed us to adapt reality to this literary formula. Even though talking of a general climate of fear would be an exaggeration, the truth is that, for a few weeks in southern Angola, there were constant fears among both civilians and military that the Kwamatos could cross the river, attack Humbe and advance on Lubango, and some of the latter advocated leaving the Fort of Humbe for fear of such an attack.

As for anger, that sentiment was clear in the desire for revenge and retaliation expressed by Portuguese society, which led to the appointment of committees and the drawing up of plans to renew the colonial armament and to prepare a punitive expedition, which never did happen along the lines recommended at the time. 
On the other hand, for a society that clearly held a perspective of civilizational superiority in relation to the indigenous peoples, the defeat was not only a humiliation but also a profound shock in face of the climate of euphoria that was beginning to emerge as a result of the latest successful campaigns.

In any case, the feelings of shock were intense - as can be seen from the impact of the political and social shockwaves -, but also brief, and few lessons were learned from the event. The belief that the defeat was the result of individual error, and above all of circumstantial vicissitude, contributed to this state of affairs and meant that, essentially, nothing had to change. In fact, when considering the arguments on the table, these were used primarily as political weapons and the attempts to find explanations were not always aligned with a reformist stance. That is, in the discussions then held in the various areopagi, few had attempted to find proposals that did more than serve corporate interests, and even the reflection on the causes of the defeat always seemed more geared towards immediate political gain or protecting class interests, or even settling old scores, than towards a true analysis of the events that could lead to changes in the models of action.

It may be true that, of the different arguments brandished at the time which sought a reason for the defeat, many were not decisive, such as the definition of objectives and even the management of human and material resources, which generally suited their purpose, but the truth remains that others, such as the lack of training of officers and subsequent logistical and tactical mistakes, appear to have been decisive for the fatal outcome. However, and due to the above-mentioned, none of these flaws were remedied, and the same mistakes continued to be made, despite some important innovations by Alves Roçadas in later campaigns.

Admittedly, for various reasons, these errors no longer had the same consequences, although in 1915, during the Môngua battle, Pereira D'Eça made the same tactical errors, forming the square for nine hours and completely exhausting the Portuguese soldiers, and it was only because they had plenty of ammunition and, most of all, because they received reinforcements in time that they did not suffer yet another defeat. But it is also true, despite the brave and often heroic action of the Portuguese troops, that the great objectives that were achieved by the end of the 1920s owed more to the action of diplomacy than that of arms, as the latter, for a number of different reasons, but also for the lack of institutional capacity to learn from past mistakes, could not have achieved it on their own. 